\title{
A preliminary study of the anisotropy of magnetic susceptibility (AMS) of Boroujerd granitoids, Sanandaj-Sirjan Zone, West Iran
}

\author{
Jamal Rasouli $^{1}$, Vahid Ahadnejad ${ }^{2 *}$, Dariush Esmaeily ${ }^{1}$ \\ ${ }^{1}$ School of Geology, College of Science, University of Tehran, PO BOX 13395-3697, Tehran, Iran \\ ${ }^{2}$ Department of Geology, Payame Noor University, Tehran, Iran; ${ }^{*}$ Corresponding Author: v.ahadnejad@pnu.ac.ir
}

Received 9 March 2011; revised 31 October 2011; accepted 1 December 2011

\begin{abstract}
The Boroujerd pluton (ca $175 \mathrm{Ma}$ ) was emplaced in the Sanandaj-Sirjan zone (SSZ) active margin of Central Iran consists of monzogranite, granodiorite, and quartz-diorite. Microstructural studies show a continuum from magmatic to (sub) mylonitic deformations fabric. Intensity of deformation decreases from W-NW to E-SE. The overall magnetic fabric of the pluton yields steep NWSE striking foliations and sub-horizontal lineations plunging both to the northwest and southeast. These features imply that during intrusion of the pluton, a NW-SE trending stretching was dominant. This stretching is ascribed to the transpressive deformation of the overriding SSZ during northeastward subduction of the Neotethys under the Iranian plate. The NW-SE trending lineations of the Gousheh pluton (ca $35 \mathrm{Ma}$ ) suggest that the transpressive regime was ongoing from the Mesozoic to late Eocene.
\end{abstract}

Keywords: Gousheh; Boroujerd; Sanandaj-Sirjan; Iran; AMS; Granitoid; Neotethys

\section{INTRODUCTION}

The geochronology of the Boroujerd pluton is well constrained by U-Pb zircon ages of Ahmadi-Khalaji [1] which showed that the rocks yield ages within the interval of $171-175 \mathrm{Ma}$. These ages are similar to other plutons dated in the Hamadan-Aligudarz section of SSZ [24], defining a main Middle-Jurassic magmatic event, lasting from 162 to $187 \mathrm{Ma}$.

The Boroujerd pluton is a regionally extensive plutonic assemblage that crops out within the garnet- and andalusite-bearing metasedimentary rocks of Hamadan Phyllites in the Sanandaj-Sirjan Zone (SSZ) of the West Iran (Figure 1; [1]). The Boroujerd pluton is important in the regional tectonomagmatic evolution because it exemplifies a pluton emplaced in transpressional tectonic regime within the of oblique subduction zone between Iranian and Arabian plates, represented by the SSZ. Obliquely convergent orogens are a suitable tectonic setting which leads to continuous and massive granite magma production [5] because the continental crust becomes thicker and, therefore hotter, which, together with heat advection from the mantle, promotes crustal melting.

In this paper, the structural and magnetic fabric were analysed for Boroujerd pluton as a part of multidisciplinary study of the plutons to assess the relationships between plutonism and deformation in the SSZ. The work focused mainly on detailed hand and core sampling for mapping the pervasive fabrics developed in the pluton during the magmatic, low to high-temperature subsolidus, and mylonitic deformations that accompanied and followed the emplacement. In general, fabrics in rocks were measured by using two methods: field observations and/or Anisotropy of Magnetic Susceptibility (AMS) measurements. In the case of weak fabrics that could not be observed in the field (i.e. granitoids), the AMS technique is based on the relationship between magnetic and mineral fabrics in rocks [6-8]. In the studied area, the fabrics were systematically mapped on a sampling grid (95 sites distributed over about the $400 \mathrm{~km}^{2}$ map area) using the lowfield anisotropy of magnetic susceptibility (AMS) technique $[9,10]$.

The magnetic fabrics are homogeneously oriented at the outcrop scale, and its pattern follow the regional strain pattern field.

\section{GEOLOGICAL SETTING}

\subsection{Regional Framework}

The Boroujerd pluton belongs to the northwestern part of the SSZ (Figure 1), a major, NW-SE trending structure, with a width of $150-250 \mathrm{~km}$ occupying a position between the Tertiary Urumieh-Dokhtar magmatic belt in 

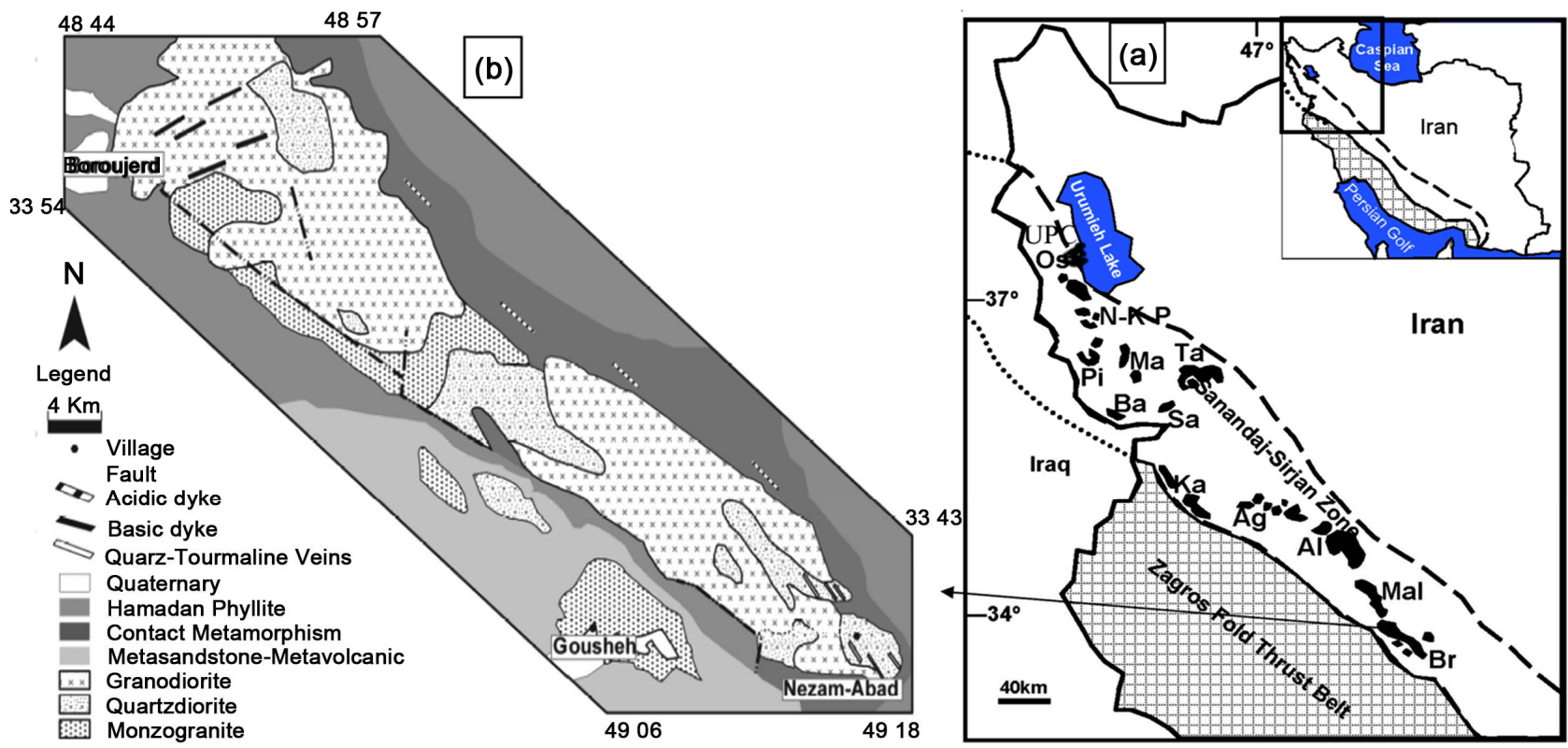

Figure 1. Geological sketch of the Boroujerd pluton. (a) The small map shows the Sanandaj-Sirjan Zone position in Iran, and the most important plutonic bodies are shown in larger figure: UPC: Urumieh Putonic Complex; OS: Oshnavieh; N-K-P: NaqadehKhalifanPasveh; Pi: Piranshahr; Ma: Mahabad; Ta, Takab; Ba: Baneh; Sa: Saqqez; Ka: Kamyaran; Ag: Almogholgh; Al: Alvand; Mal: Malayer; Br: Boroujerd; (b) Geological map of the Boroujerd pluton.

the northeast and Cretaceous-Tertiary Zagros fold thrust belt in the southwest. The SSZ is a segment of AlpineHimalayan magmatic belt that includes voluminous basic to felsic igneous rocks. They have mainly calc-alkaline affinity and are attributed to the subduction of an Neotethyan oceanic slab beneath central Iranian plate in the Mesozoic time [11,12].

The SSZ was first recognized as a separate linear structural element by Stöcklin [13] and is one of the most dynamic structural zones of Iran and possesses complex structural and stratigraphic features $[14,15]$. It joins the Taurus orogenic belt in Turkey. The zone occupies a NW-trending $1500 \mathrm{~km}$ belt in which the Zagros structural grain is overprinted by the typical Central Iran structural framework [16]. The northeastern part of the SSZ contains a series of elongated depressions that are well developed parallel to the southwestern boundary of the Urumieh-Dokhtar magmatic assemblage [15]. Negative bouguer anomaly shows an elevation increase toward the southwest [17] and it appears that from NE to SW crustal thickness of the SSZ increase through the SSZ from $40 \mathrm{~km}$ in the NE to $55 \mathrm{~km}$ in the SW.

\subsection{Boroujerd Pluton}

The Boroujerd calc-alkaline and peraluminous to metaluminous granitoids pluton are between the Boroujerd city and the Nezam-Adab village, and occupy an area of ca $400 \mathrm{~km}^{2}$. It cropsout along a broad NW-SE trending area within the regionally metamorph rocks and is formed by two bodies: the Boroujerd and Gousheh bodies (Fig- ure 1). The field and petrographic studies show that this pluton contains a wide range of rocks from granite, granodiorite to diorite along with acidic (pegmatite and aplite), basic and intermediate dikes and quartz tourmaline veins, although granodiorite and quartz-diorite are dominant rock types. The granodiorite which forms the northern part of pluton, and is intruded by NE-SW striking basic dikes (Figures 1 and 2(a)). The granitoids have granular textures and are composed of plagioclase, alkalifeldspar, quartz and biotite. The accessory minerals are allanite, apatite, sphene, zircon and opaques.

$\mathrm{The} \mathrm{Rb} / \mathrm{Sr}$ ages on the pluton [18] indicated that it is crystallized during early to Late Cretaceous, but recent $\mathrm{U}-\mathrm{Pb}$ zircon ages indicate a middle-Jurassic age for pluton [8]. The geochemical signature of the pluton ranges from metaluminous to slightly peraluminous and it typically shows S-type characteristics. It belongs to high-K calc-alkaline series and displays the geochemical characteristics typical of volcanic arc granites related to an active continental margin (e.g. significant $\mathrm{Nb}, \mathrm{Ti}, \mathrm{P}$ and $\mathrm{Sr}$ depletion). Isotopic data $\left(\mathrm{Sr}_{\mathrm{i}}=0.7062-0.7074\right.$ and $\varepsilon \mathrm{Ndt}=-3.02$ to -3.62$)$ are consistent with a crustal protolith [1].

Spatially separated from the Boroujerd pluton, about 5 $\mathrm{km}$ to the south, is the Gousheh pluton, mainly consisting of gray-coloured monzogranite. The rocks of this intrusive body are calc-alkaline and metaluminous, and have S-type characteristics [19]. At the outcrop scale, it appears relatively homogeneous in compositions, but microscopic studies show that the intrusive rocks vary from 

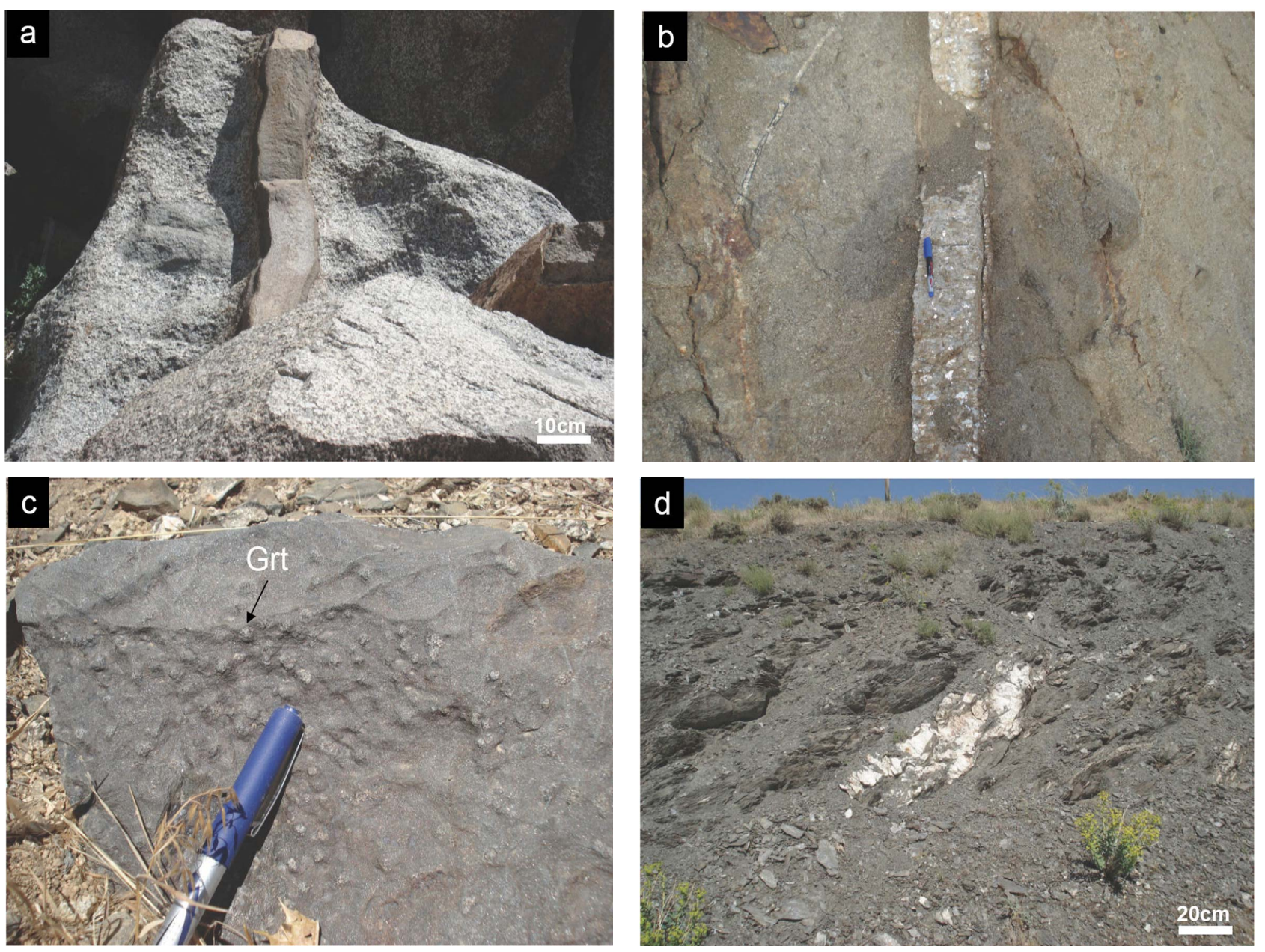

Figure 2. (a) The mafic dikes are generally intruded into the granitoids in the NE-SW direction; (b) Granitoids hosting quartz pegmatite dykes; (c) Contact metamorphism formed the garnet-andalusite schist in the inner zone of thermal aureole; (d) Low grade regional metamorphic rocks in the southern part of the pluton.

alkali granite to granite and minor granodiorite with a granular textures. The microgranular mafic, pegmatites and quartz veins are frequently observed (Figures 2(a), (b)). The U-Pb system on zircon ages for the Gousheh intrusion indicates a ca $35 \mathrm{Ma}$ for its crystallization [8]. Razavi et al. [20] indicate that this body is post-orogenic and a within plate granite. The intrusive rocks of the area have caused thermal contact metamorphism in their surrounding Paleozoic and Mesozoic sediments including meta-volcanic and meta-limestones/dolomites of Paleozoic and Triassic age [21].

Metamorphism evolution occurred as low grade regional metamorphism and low to high grade contact metamorphism. Contact metamorphism inception is characterized by spotted (garnet-andalusite) schist (Figure 2(c)) and ends to hornfels assemblages, where as the regional metamorphism is found in under green-schist facies conditions. These rocks experienced high temperature-low pressure contact metamorphism during injection of granitic magma across their schistosity plane. In the southern part of the complex, contact metamorphism is poor, although there is a narrow band of schist with cordierite or hornfels cordierite and also is ended to slate and phyllite (Figure 2(d)). However, in northern part the hornfels occurs.

\section{MICROSTRUCTURES OF THE PLUTONS}

For accurate interpretation of the internal structures of a pluton, we need a detailed study of its microstructures in order to show whether deformation occurred in the magmatic state, solid state (high or low temperature), or mylonitic state. Field and petrographic studies show that the deformation intensity through the pluton is heterogeneously distributed decreases from W-NW to E-SE. For example, in the corners of monzogranites, no deformation fabrics could be observed, whereas, in north and northwest of the complex, mylonitic microstructures are abundant. 
For microstructural studies we used thin-sections obtained from our AMS and hand samples. We sued as a basis the previous studies on granitic microstructures that classified deformations into magmatic, high- to moderate-temperature solid state, and low temperature types along with mylonitization [22-24].

\subsection{Magmatic Microstructures}

Microstructures indicative of magmatic flow are observed only within the Gousheh intrusive body, where the rock-forming minerals do not show any evidence for metamorphic reactions or tectonic deformation. Very weak undulatory extinction is found in quartz whereas feldspar crystals are undeformed. In some rocks there are signs of deformation, with the feldspars fractured in what was probably is a submagmatic state as defined by Bouchez et al. [25] (Figure 3(a)). The biotites and subgrain boundaries in the quartz crystals display some bends which are considered as mechanical interactions between crystals in a magma where the residual melt content was possibly much less than $30 \%$ [26,27]. The other crystals in this body remain undeformed.
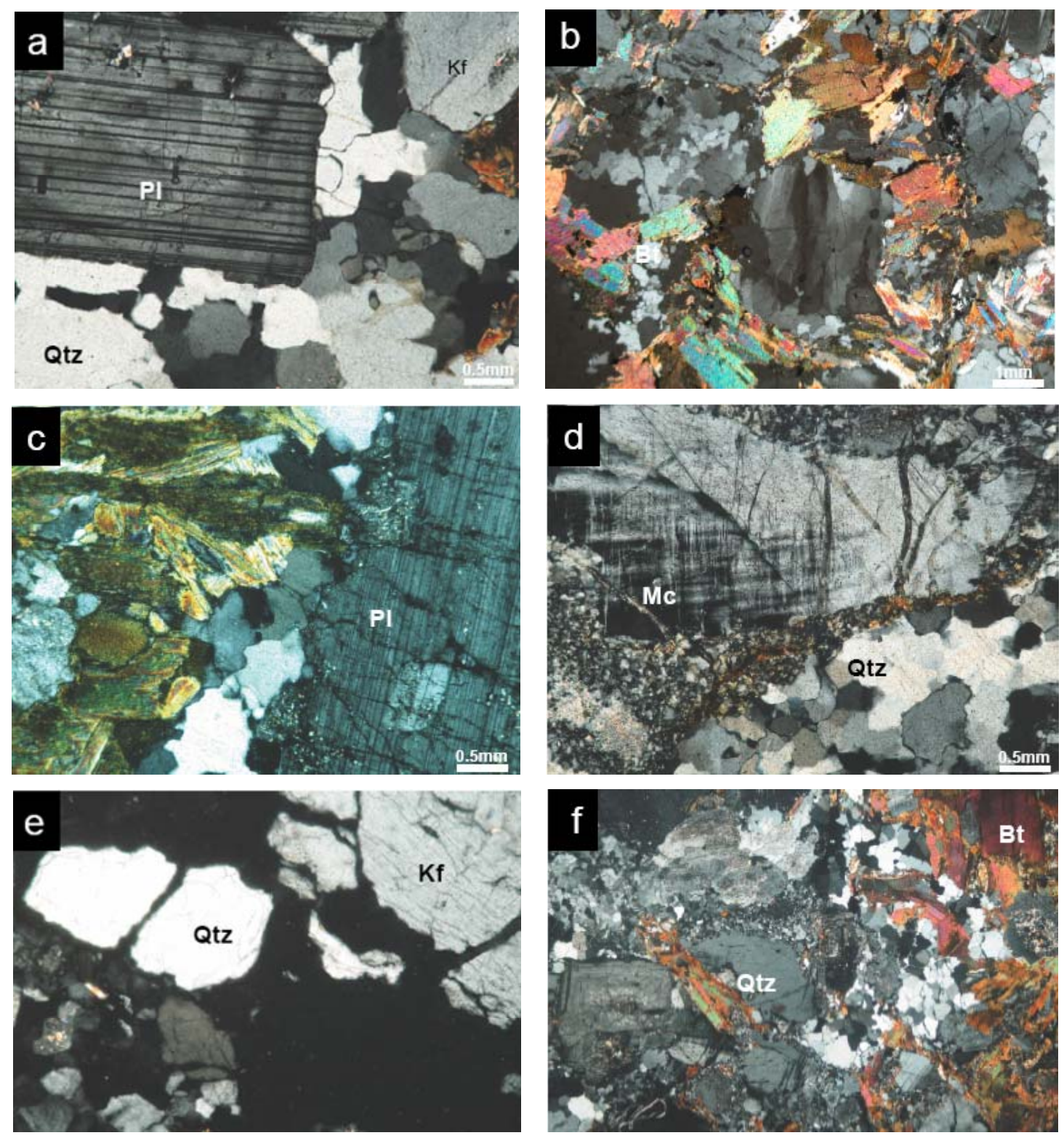

Figure 3. (a) Fractures in plagioclase indicate submagmatic flow; (b) Kinking of biotite is very common in the samples; (c) Polysynthetic twinning in plagioclase which was formed during high-temperature deformation; (d) Recrystallization texture of quartz crystals on the low-temperature deformation; (e) Mylonitic microstructures imply high rates of strain in the studied region; (f) Recrystallisation and grain growth of quartz under high rates of stress. 


\subsection{High Temperature Solid State Microstructures}

Microstructures of this type occurre at the end of or shortly after the complete crystallization of the magma, and are found in the east-southeast corner to the center of the Boroujerd pluton. The biotite crystals have been convolute and kinked in the most intensely deformed rocks in this zone (Figure 3(b)). The edges of the plagioclase crystals have been crushed and show polysynthetic twins (Figure 3(c)). The perthitic texture is common in feldspars. Re-crystallization has occurred in quartz crystals and their subgrains exibit mosaics with chessboard patterns. The grain-boundary migration of quartz caused an evolvement of subgrains into new grains.

\subsection{Low Temperature Microstructures}

The low temperature microstructures are developed in the centre to west-southwest side of the Boroujerd pluton. The small re-crystallized grains are mostly distributed along the boundaries and within wrench fractures of large grains of quartz (Figure 3(d)). In some rocks, the biotite is transformed into chlorite and the plagioclase is partly replaced by sericite.

\subsection{Mylonitic Deformations}

The mylonitic and sub-mylonitic microstructures are mainly observed within shear zones. The sub-mylonitic microstructures are mostly found in the northeast of the complex, while the mylonitic microstructures are developed in the northwest (Figure 3(e)). The biotites are intensely altered and converted to muscovite, epidote and chlorite. In some parts of this zone, mica fish microstructures are developed. Dynamic recrystallization and undulatory extinction are common in quartz (Figure 3(f)).

\section{AMS ANALYSIS}

Ninety-five sampling sites were established within the Boroujerd pluton (Figure 4). Drilling was done in 95 stations in different lithological units of the complex. Sampling at each site was performed with a portable benzin drill. At each station, at least two $25 \mathrm{~mm}$ in-diameter oriented cores, a few meters apart, were drilled. Each core was cut into 2 to 7 cylindrical specimens, $22 \mathrm{~mm}$ inheight, adapted to the sample holder of the susceptometer.

The measurements of AMS and bulk susceptibility was taken using a KLY3 ${ }^{\mathrm{TM}}$ susceptometer of Agico Ltd (Brno, Czech Republic) that uses an alternating low-field

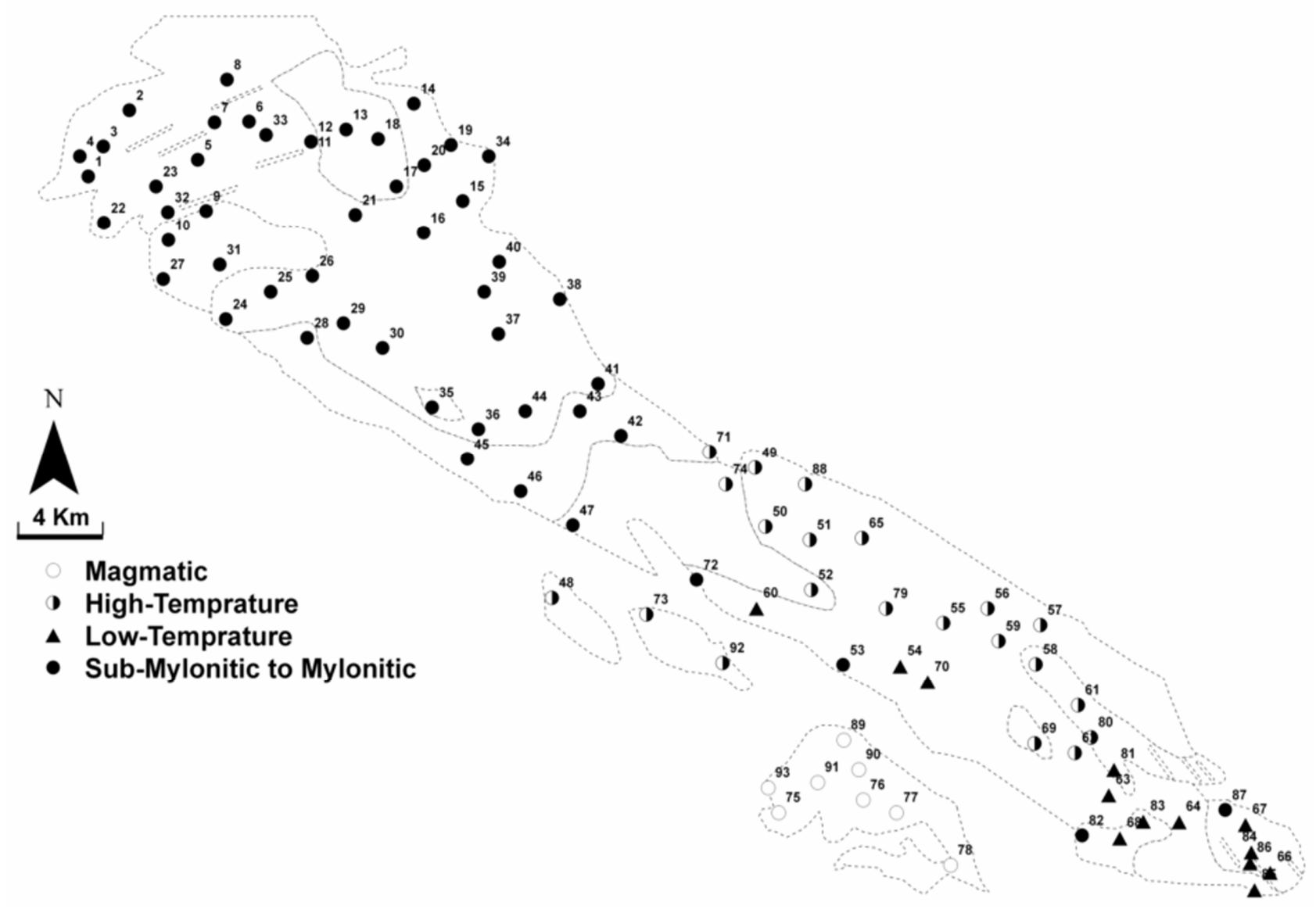

Figure 4. Sampling stations (95 sites) used for the magnetic fabric study. 
of $4 \times 10^{-4}$ Tesla $(920 \mathrm{~Hz})$ and has a sensitivity of $5 \times$ $10^{-8} \mathrm{SI}$ at the University of Toulouse, France. These measurements allow the orientation and magnitude of the three main axes $\left(K_{1} \geq K_{2} \geq K_{3}\right)$ of the magnetic susceptibility ellipsoid to be determined. For defining the mean ellipsoid representative of the magnetic fabric of the site, we used their tensorial mean, measured on all the specimens of each site. The results enable us to define the bulk susceptibility $\left(K_{m}=\left(K_{1}+K_{2}+K_{3}\right) / 3\right)$, magnetic lineation $\left(K_{1}\right)$ and foliation (plane normal to $K_{3}$ ), which usually are parallel to the mineral lineation and foliation, respectively. Furthermore, the principal fabric parameters such as anisotropy percentage $\left[P \%=\left(\left(K_{1} / K_{3}\right)-1\right) \times 100\right]$ and the shape parameter $\left[T=\left[\ln \left(K_{2} / K_{3}\right)-\ln \left(K_{1} / K_{3}\right)\right] /[\ln \right.$ $\left.\left(K_{2} / K_{3}\right)+\left(\ln \left(K_{1} / K_{2}\right)\right]\right]$ can be calculated.

The petrographic study of samples suggests that biotite, and amphibole to a lesser extent, are the main paramagnetic contributors. Therefore, in the paramagnetic granites such as the Boroujerd pluton, $K_{m}$ is proportional to the iron content of the iron-bearing silicates and susceptibility can be directly correlated to the modal content of biotite and amphibole. In the other words, the bulk susceptibility $\left(K_{m}\right)$ map showing the spatial variation of $K_{m}$ mainly reflects the biotite content, and the directional measurements of AMS magnetic fabric reflect the preferential orientation of sheet silicates [28-30]. The results imply that magnetic fabrics are predominantly controlled by the preferred orientations of paramagnetic minerals (e.g. biotite plus an accessory fraction of amphibole) although chlorite that has locally replaced biotite and very fine-grained magnetite contribute to the magnetic susceptibility and to the AMS as well. In these paramagnetic rocks, several studies [31] have shown that the value of $\mathrm{P}_{\text {para }} \%$ correlates with the amount of deformation. The behavior of the shape parameter $T$ is more complex since it depends on both the amount of biotite in the specimen and the deformation regime [32]. Generally, AMS has been used to constrain the kinematics of magma emplacement [33-35].

In this study, the main objectives were to establish a database of the magnetic lineation and foliation preserved in the rocks and compare them with known deformation events to decipher the mechanism of emplacement.

\subsection{Bulk Susceptibility}

In order to classifying magnetic susceptibility on the contoured map we classify them in three groups ( $\mu \mathrm{SI}): 1$ ) $10<K_{m}<160$; 2) $116<K_{m}<260$; 3) $261<K_{m}<920$ (Figure 5). The values of $K_{m}(\mu \mathrm{SI})$, ranging from 14 (monzogranites) to 921 (quartz-diorites), can be correlated with the rock types as follows (Table 1): monzogranite $32<K_{m}<330$, granodiorite $14<K_{m}<647$, quartz-diorite $72<K_{m}<922$. Such a rather wide range of susceptibilities is common in the large plutons of the SSZ, as for instance the nearby Malayer pluton [36] which reflects the diversity of the plutonic rocks of the SSZ.

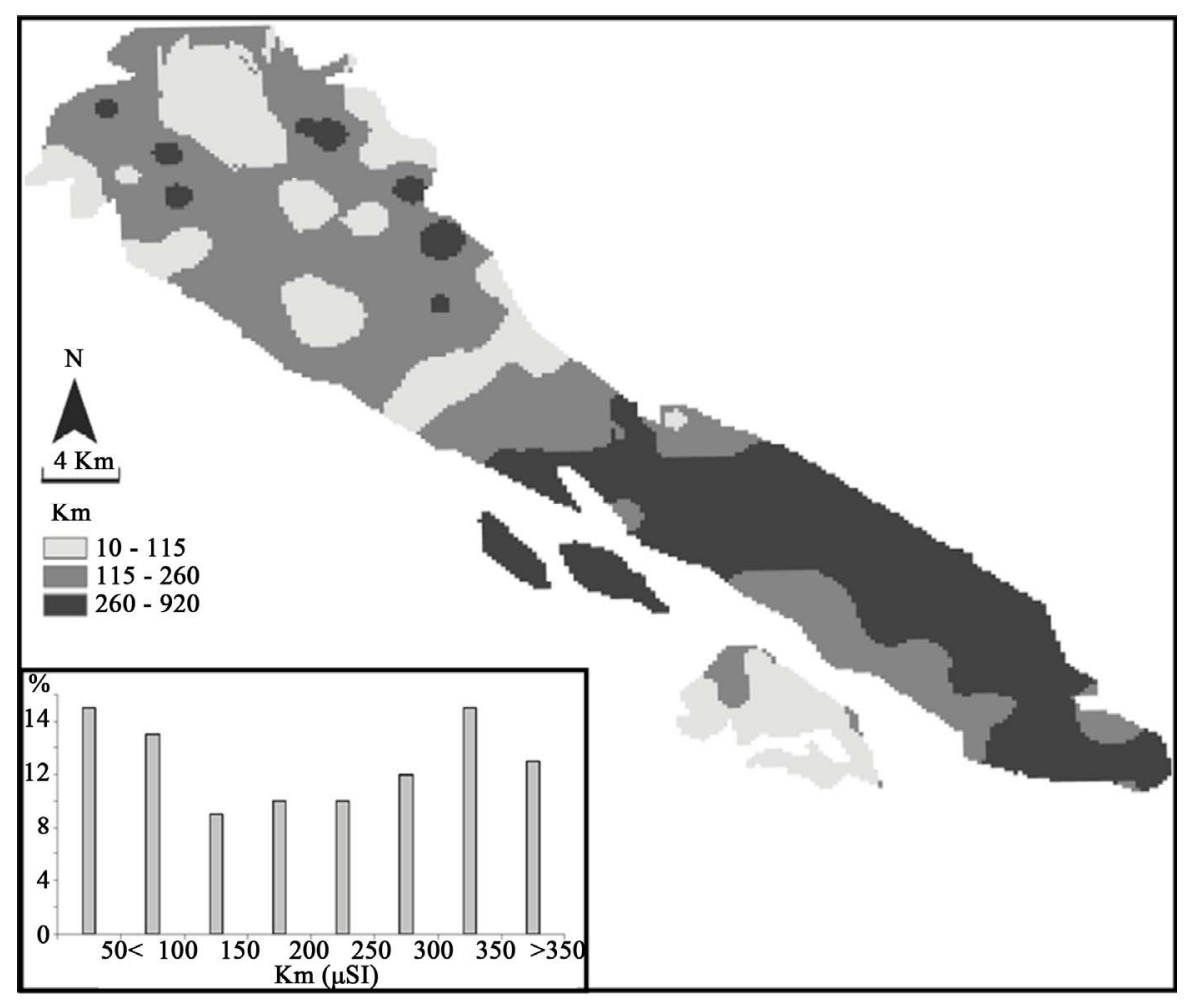

Figure 5. Contoured map and histogram of the bulk susceptibilities $(K)$. 
Table 1. AMS data for the Boroujerd pluton.

\begin{tabular}{|c|c|c|c|c|c|c|c|c|c|}
\hline Site & $\mathrm{N}$ & Rock type & $X$ & $\mathrm{Y}$ & $\mathrm{Km} \mu \mathrm{SI}$ & Lin. Az/pl. & $\begin{array}{l}\perp \text { Fol. } \\
\text { Az/dip }\end{array}$ & $P(\%)$ & $T$ \\
\hline 1 & 6 & $\mathrm{Gd}$ & 295269 & 3758114 & 17 & $232 / 25$ & $139 / 06$ & 1.7 & -0.03 \\
\hline 2 & 5 & $\mathrm{Gd}$ & 296952 & 3761130 & 293 & 089/04 & $201 / 80$ & 9.1 & 0.54 \\
\hline 3 & 4 & $\mathrm{Gd}$ & 295890 & 3759488 & 214 & $133 / 22$ & $032 / 23$ & 3.7 & -0.16 \\
\hline 4 & 5 & $\mathrm{Gd}$ & 294956 & 3759046 & 107 & $185 / 50$ & $280 / 04$ & 4.6 & 0.04 \\
\hline 5 & 4 & Gd & 299599 & 3758792 & 349 & $183 / 47$ & $077 / 14$ & 5.6 & -0.49 \\
\hline 6 & 2 & $\mathrm{Gd}$ & 301664 & 3760506 & 14 & $340 / 10$ & $126 / 78$ & 6.2 & 0.49 \\
\hline 7 & 2 & $\mathrm{Gd}$ & 300303 & 3760503 & 32 & $186 / 40$ & $297 / 23$ & 5.6 & -0.09 \\
\hline 8 & 6 & $\mathrm{Gd}$ & 300832 & 3762465 & 93 & $191 / 02$ & $286 / 71$ & 2.4 & 0.31 \\
\hline 9 & 3 & MG & 299883 & 3756413 & 330 & $164 / 26$ & $052 / 36$ & 4.0 & -0.30 \\
\hline 10 & 5 & MG & 298365 & 3755089 & 169 & $359 / 15$ & $241 / 61$ & 6.5 & 0.31 \\
\hline 11 & 5 & $\mathrm{Gd}$ & 304084 & 3759531 & 34 & $139 / 08$ & $293 / 82$ & 2.3 & -0.31 \\
\hline 12 & 6 & $\mathrm{Gd}$ & 304084 & 3759531 & 64 & $141 / 14$ & $301 / 75$ & 2.7 & 0.41 \\
\hline 13 & 6 & Q-Di & 305481 & 3760057 & 303 & $154 / 06$ & $256 / 63$ & 5.3 & -0.63 \\
\hline 14 & 3 & $\mathrm{Gd}$ & 308175 & 3761204 & 28 & $207 / 79$ & $311 / 03$ & 2.4 & -0.76 \\
\hline 15 & 6 & $\mathrm{Gd}$ & 310010 & 3756667 & 355 & $126 / 33$ & $252 / 42$ & 7.3 & 0.32 \\
\hline 16 & 6 & $\mathrm{Gd}$ & 308440 & 3755219 & 40 & $277 / 08$ & $175 / 56$ & 2.0 & 0.68 \\
\hline 17 & 6 & Q-Di & 307405 & 3757398 & 255 & $144 / 01$ & $234 / 09$ & 5.8 & -0.40 \\
\hline 18 & 6 & Q-Di & 306730 & 3759600 & 403 & $219 / 22$ & $325 / 33$ & 0.4 & 0.46 \\
\hline 19 & 6 & $\mathrm{Gd}$ & 309600 & 3759264 & 22 & 037/09 & $304 / 15$ & 2.3 & -0.13 \\
\hline 20 & 5 & Gd & 308529 & 3758361 & 39 & $103 / 34$ & $335 / 42$ & 3.0 & -0.55 \\
\hline 21 & 7 & Gd & 305760 & 3756106 & 22 & $137 / 25$ & $234 / 14$ & 2.3 & -0.04 \\
\hline 22 & 6 & Gd & 295839 & 3755945 & 43 & $023 / 46$ & $269 / 21$ & 1.4 & 0.57 \\
\hline 23 & 6 & Gd & 297930 & 3757595 & 78 & $081 / 23$ & $330 / 40$ & 2.0 & -0.19 \\
\hline 24 & 6 & Gd & 300548 & 3751375 & 129 & $040 / 19$ & $284 / 52$ & 4.1 & -0.25 \\
\hline 25 & 3 & $\mathrm{Gd}$ & 302347 & 3752601 & 211 & $029 / 41$ & $274 / 26$ & 3.5 & -0.32 \\
\hline 26 & 6 & $\mathrm{Gd}$ & 304007 & 3753307 & 219 & $151 / 32$ & $303 / 55$ & 5.5 & -0.59 \\
\hline 27 & 4 & MG & 298121 & 3753276 & 58 & $344 / 08$ & $230 / 71$ & 12.1 & -0.02 \\
\hline 28 & 4 & $\mathrm{Gd}$ & 303742 & 3750446 & 138 & $159 / 27$ & $333 / 63$ & 3.4 & 0.35 \\
\hline 29 & 4 & $\mathrm{Gd}$ & 305195 & 3751094 & 76 & $072 / 18$ & $325 / 42$ & 1.3 & 0.47 \\
\hline 30 & 5 & $\mathrm{Gd}$ & 306713 & 3749923 & 51 & $159 / 27$ & $040 / 72$ & 1.8 & 0.62 \\
\hline 31 & 5 & MG & 300370 & 3753906 & 32 & $332 / 07$ & $227 / 65$ & 1.8 & -0.44 \\
\hline 32 & 5 & $\mathrm{Gd}$ & 298367 & 3756384 & 199 & $351 / 07$ & $252 / 50$ & 5.1 & 0.26 \\
\hline 33 & 4 & $\mathrm{Gd}$ & 302319 & 3759876 & 46 & $132 / 03$ & $042 / 04$ & 1.3 & 0.01 \\
\hline 34 & 5 & $\mathrm{Gd}$ & 311079 & 3758711 & 26 & $194 / 30$ & $286 / 04$ & 1.8 & 0.25 \\
\hline 35 & 2 & MG & 308611 & 3747141 & 203 & $069 / 36$ & $231 / 53$ & 0.8 & 0.09 \\
\hline 36 & 5 & $\mathrm{Gd}$ & 310416 & 3746088 & 49 & $148 / 15$ & $264 / 59$ & 3.5 & -0.29 \\
\hline 37 & 5 & $\mathrm{Gd}$ & 311300 & 3750478 & 281 & $355 / 25$ & $251 / 29$ & 3.9 & -0.57 \\
\hline 38 & 5 & Gd & 313747 & 3752032 & 38 & $036 / 33$ & $283 / 31$ & 1.1 & -0.09 \\
\hline 39 & 3 & Gd & 310773 & 3752430 & 256 & $034 / 13$ & $217 / 77$ & 2.7 & -0.51 \\
\hline 40 & 5 & Gd & 311392 & 3753804 & 343 & $354 / 05$ & 084/09 & 2.2 & 0.21 \\
\hline 41 & 3 & $\mathrm{Gd}$ & 315187 & 3748090 & 27 & $049 / 34$ & $319 / 00$ & 3.3 & 0.14 \\
\hline 42 & 6 & MG & 316040 & 3745670 & 122 & $319 / 21$ & $073 / 47$ & 2.8 & 0.17 \\
\hline 43 & 2 & MG & 314442 & 3746841 & 123 & $124 / 43$ & $340 / 41$ & 1.5 & 0.16 \\
\hline 44 & 6 & $\mathrm{Gd}$ & 312283 & 3746883 & 93 & $021 / 48$ & $263 / 23$ & 0.7 & -0.30 \\
\hline 45 & 6 & MG & 309951 & 3744711 & 92 & $176 / 39$ & $331 / 49$ & 1.1 & -0.18 \\
\hline 46 & 3 & MG & 312030 & 3743159 & 187 & $112 / 29$ & $227 / 38$ & 4.4 & 0.55 \\
\hline 47 & 6 & Q-Di & 314056 & 3741548 & 349 & $100 / 67$ & $215 / 11$ & 1.7 & -0.17 \\
\hline 48 & 4 & MG & 313167 & 3738206 & 278 & $334 / 05$ & $195 / 48$ & 5.3 & 0.15 \\
\hline 49 & 6 & $\mathrm{Gd}$ & 321308 & 3744090 & 62 & $276 / 01$ & $184 / 64$ & 0.8 & -0.16 \\
\hline 50 & 3 & $\mathrm{Gd}$ & 321668 & 3741341 & 280 & $270 / 28$ & $017 / 29$ & 4.6 & 0.53 \\
\hline 51 & 3 & $\mathrm{Gd}$ & 323405 & 3740692 & 313 & $294 / 01$ & $024 / 02$ & 3.4 & -0.40 \\
\hline 52 & 6 & Q-Di & 323414 & 3738381 & 467 & $299 / 17$ & $208 / 03$ & 3.4 & 0.55 \\
\hline 53 & 3 & $\mathrm{Gd}$ & 324592 & 3736695 & 470 & $258 / 42$ & $165 / 04$ & 4.2 & 0.52 \\
\hline 54 & 6 & Gd & 324610 & 3734877 & 194 & $317 / 13$ & $210 / 51$ & 8.3 & 0.54 \\
\hline 55 & 3 & $\mathrm{Gd}$ & 326874 & 3734774 & 167 & $126 / 10$ & $231 / 57$ & 5.5 & -0.41 \\
\hline
\end{tabular}


Continued

\begin{tabular}{|c|c|c|c|c|c|c|c|c|c|}
\hline 56 & 6 & $\mathrm{Gd}$ & 328609 & 3736745 & 306 & $315 / 10$ & $046 / 05$ & 3.3 & 0.13 \\
\hline 57 & 5 & $\mathrm{Gd}$ & 330370 & 3737392 & 360 & $174 / 07$ & $326 / 82$ & 3.5 & 0.32 \\
\hline 58 & 6 & Q-Di & 332441 & 3736585 & 314 & $343 / 24$ & $244 / 19$ & 3.0 & -0.61 \\
\hline 59 & 2 & $\mathrm{Gd}$ & 332229 & 3734771 & 387 & $324 / 11$ & $233 / 02$ & 3.3 & -0.51 \\
\hline 60 & 2 & $\mathrm{Gd}$ & 330781 & 3735875 & 309 & $164 / 33$ & $038 / 42$ & 5.5 & 0.46 \\
\hline 61 & 5 & Q-Di & 321237 & 3737558 & 268 & $321 / 04$ & $229 / 24$ & 9.0 & 0.13 \\
\hline 62 & 3 & $\mathrm{Gd}$ & 319228 & 3736148 & 425 & $058 / 39$ & $187 / 37$ & 4.7 & 0.69 \\
\hline 63 & 2 & $\mathrm{Gd}$ & 333868 & 3732831 & 380 & $140 / 74$ & $022 / 08$ & 5.0 & 0.36 \\
\hline 64 & 5 & $\mathrm{Gd}$ & 333701 & 3730647 & 277 & $077 / 75$ & $202 / 08$ & 6.3 & 0.17 \\
\hline 65 & 4 & $\mathrm{Gd}$ & 335007 & 3728683 & 197 & $314 / 77$ & $200 / 05$ & 3.1 & -0.23 \\
\hline 66 & 4 & Q-Di & 337767 & 3727403 & 299 & $061 / 42$ & $177 / 26$ & 2.1 & -0.05 \\
\hline 67 & 4 & Q-Di & 325464 & 3740747 & 296 & $117 / 08$ & $300 / 82$ & 3.9 & 0.87 \\
\hline 68 & 6 & Q-Di & 341334 & 3725033 & 493 & $101 / 62$ & 207/09 & 7.1 & 0.17 \\
\hline 69 & 2 & Q-Di & 340392 & 3727236 & 143 & $111 / 00$ & $021 / 12$ & 5.0 & -0.38 \\
\hline 70 & 3 & $\mathrm{Gd}$ & 335411 & 3726704 & 314 & $006 / 25$ & $255 / 38$ & 3.1 & 0.52 \\
\hline 71 & 5 & MG & 332113 & 3731106 & 178 & $089 / 25$ & $196 / 33$ & 5.6 & 0.52 \\
\hline 72 & 6 & $\mathrm{Gd}$ & 327942 & 3734015 & 249 & $127 / 04$ & $219 / 28$ & 4.4 & -0.97 \\
\hline 73 & 4 & Q-Di & 319522 & 3744863 & 321 & $117 / 00$ & $026 / 79$ & 3.5 & 0.07 \\
\hline 74 & 6 & Q-Di & 318895 & 3738928 & 168 & $317 / 38$ & $200 / 31$ & 7.1 & -0.19 \\
\hline 75 & 4 & MG & 316883 & 3737364 & 922 & $324 / 23$ & $216 / 36$ & 6.0 & 0.42 \\
\hline 76 & 2 & MG & 320136 & 3743342 & 292 & $253 / 25$ & $353 / 21$ & 5.6 & -0.02 \\
\hline 77 & 4 & MG & 321936 & 3728116 & 65 & $063 / 27$ & $257 / 62$ & 2.5 & -0.01 \\
\hline 78 & 4 & MG & 325295 & 3728639 & 96 & $321 / 07$ & $230 / 07$ & 2.4 & 0.44 \\
\hline 79 & 4 & $\mathrm{Gd}$ & 326597 & 3728030 & 82 & $106 / 13$ & $214 / 53$ & 2.2 & -0.15 \\
\hline 80 & 4 & Q-Di & 328692 & 3725589 & 72 & $244 / 26$ & $334 / 00$ & 9.8 & -0.35 \\
\hline 81 & 4 & Q-Di & 326357 & 3737464 & 329 & $349 / 42$ & $243 / 17$ & 4.3 & 0.49 \\
\hline 82 & 4 & Q-Di & 334357 & 3731344 & 277 & $053 / 36$ & $178 / 38$ & 2.7 & -0.23 \\
\hline 83 & 4 & Q-Di & 335233 & 3729850 & 315 & $266 / 53$ & $048 / 31$ & 3.5 & -0.55 \\
\hline 84 & 4 & Q-Di & 333919 & 3726853 & 215 & $218 / 06$ & $308 / 03$ & 1.3 & 0.84 \\
\hline 85 & 4 & Q-Di & 336351 & 3727458 & 348 & $050 / 51$ & $234 / 40$ & 1.5 & -0.75 \\
\hline 86 & 4 & Q-Di & 340603 & 3725969 & 375 & $201 / 72$ & $100 / 04$ & 1.4 & -0.45 \\
\hline 87 & 4 & Q-Di & 340703 & 3724242 & 159 & $338 / 57$ & $200 / 26$ & 3.0 & -0.13 \\
\hline 88 & 3 & $\mathrm{Gd}$ & 340543 & 3725477 & 390 & $252 / 40$ & $158 / 05$ & 1.1 & 0.25 \\
\hline 89 & 4 & MG & 339605 & 3727927 & 189 & $311 / 17$ & $220 / 03$ & 3.7 & 0.42 \\
\hline 90 & 5 & MG & 323273 & 3743283 & 225 & $321 / 05$ & $067 / 72$ & 4.4 & -0.38 \\
\hline 91 & 4 & MG & 324572 & 3731395 & 108 & $044 / 87$ & $229 / 03$ & 3.8 & 0.05 \\
\hline 92 & 4 & Q-Di & 325140 & 3730029 & 108 & $313 / 36$ & $189 / 39$ & 1.5 & -0.09 \\
\hline 93 & 4 & MG & 323507 & 3729473 & 125 & $275 / 88$ & $020 / 00$ & 2.0 & -0.03 \\
\hline 94 & 4 & $\mathrm{Gd}$ & 319851 & 3735058 & 647 & $278 / 44$ & $140 / 38$ & 5.5 & 0.94 \\
\hline 95 & 2 & $\mathrm{Gd}$ & 321545 & 3729263 & 76 & $118 / 33$ & $287 / 56$ & 1.5 & -0.47 \\
\hline
\end{tabular}

The granites have been classified into three groups on the basis of magnetic susceptibility: diamagnetic $\left(K_{m}<\right.$ $50)$, paramagnetic $\left(50<K_{m}<400\right)$, and ferromagnetic $\left(K_{m}>400\right)$. The average value of $K_{m}$ for Boroujerd granitoids is $205(\mu \mathrm{SI})$ and they can ascribed to paramagnetic granites. Locally, this value is higher or lower than paramagnetic range. For example, most of quartzdiorites of Nezam-Abad village have $K_{m}$ more than 400 $(\mu \mathrm{SI})$ and small stocks in monzogranites and granodiorites show lower than $50(\mu \mathrm{SI})$. The petrographic study of quartz-diorites shows the presence of pyroxene in these rocks. This study in the latter group indicates that opaque minerals are absent or rare and they can be considered as diamagnetic rocks. The $K_{m}$ values are lower than 300 $(\mu \mathrm{SI})$ from centre toward the north, while, it is mostly high $(>300 \mu \mathrm{SI})$ from centre to the south in the Boroujerd main body (Figure 5). In the Gousheh, the $K_{m}$ is generally low.

\subsection{Magnetite Anisotropy Degree (Ppara)}

In paramagnetic granites, the anisotropy parameter is defined as $\mathrm{P}_{\text {para }} \%=100\left[\left(K_{1}-D\right) /\left(K_{3}-D\right)-1\right]$ in which $K_{1}$ and $K_{3}$ are the maximum and minimum susceptibilities, and $D$ is the diamagnetic contribution considered to 
be constant and isotropic, and estimated as $-1.4 \times 10^{-5} \mathrm{SI}$ [4]. In these cases, a correlation exists between the bulk magnetic anisotropy and the fabric intensity, itself linked to the accumulated strain magnitude undergone by the rock in the magmatic and solid states $[37,38]$. On the distribution pattern of the anisotropy percentages, there is significant information coming from the deformation microstructures.

The mean anisotropy percentages in Boroujerd pluton is $\mathrm{P}_{\text {para }} \%=3.72$ (Table 1). The highest and lowest values are 12.09 and 0.37 , respectively. Mean $\mathrm{P}_{\text {para }} \%$ is low in north part of Boroujerd pluton $(<2 \%)$ correlating with mylonitic deformation, however, somewhere of its northwestern parts have the high anisotropies ( $>5 \%$ ) (Figure 6(a)). The southeasrern part which is covered by lowtemperature deformation shows low anisotropy as well. The intermediate anisotropy magnitudes, between 2 and $5 \%$ nearly are correspond to high-temperature deformation. The highest anisotropies $(>5 \%)$ distribution in map view is somewhat irregular which underlines the hetero- geneity of the solid-state deformation in some areas. According to classification of Olivier et al. [39], the Boroujerd granitoids with mean anisotropy of $3.72 \%$ belongs to oriented granitic rocks.

\subsection{Shape Parameter ( $T$ )}

The $T$ values cover a wide range of shapes, from strongly planar $(T=0.94)$ to strongly linear $(T=-0.97)$ within the granodiorite. The shapes of the magnetic ellipsoids are irregularly divided into planar and linear types (Figure 6(b)). In map view, the distribution of linear and planar fabrics is not regular. As a whole, there are no correlations between the the bulk susceptibility and degree of anisotropy or the shape of the AMS ellipsoid (Figures 7(a), (b)) and between the degree of anisotropy and the shape of the AMS (Figure 7(c)) in the Boroujerd pluton. These features may indicate that the values of $\mathrm{T}$ and $\mathrm{P}$ are not influenced by the petrographic variations observed in the Boroujerd massif.

\section{(a)}

Degree of anisotropy

of the magnetic elipsoid

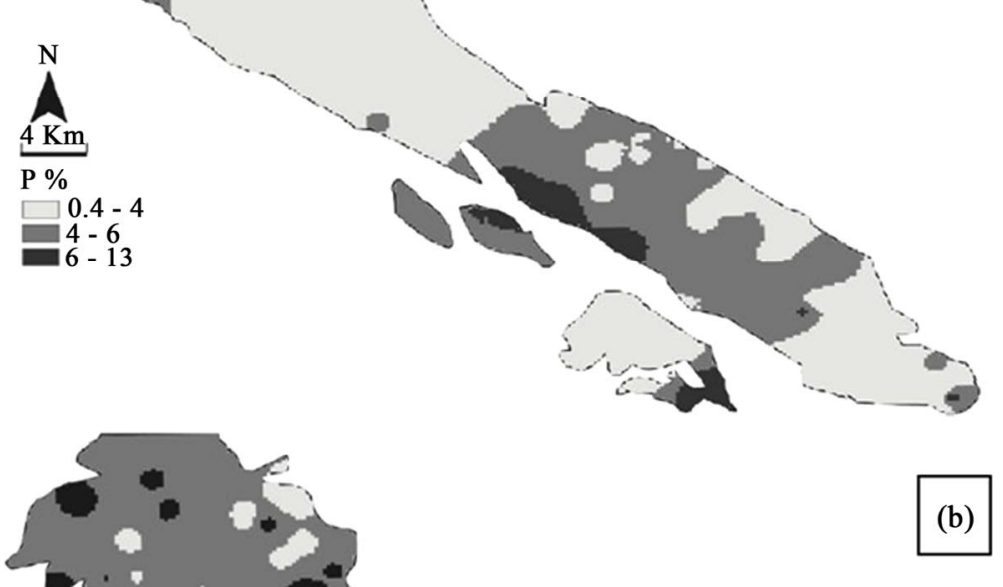

Shape of magnetic ellipsoid

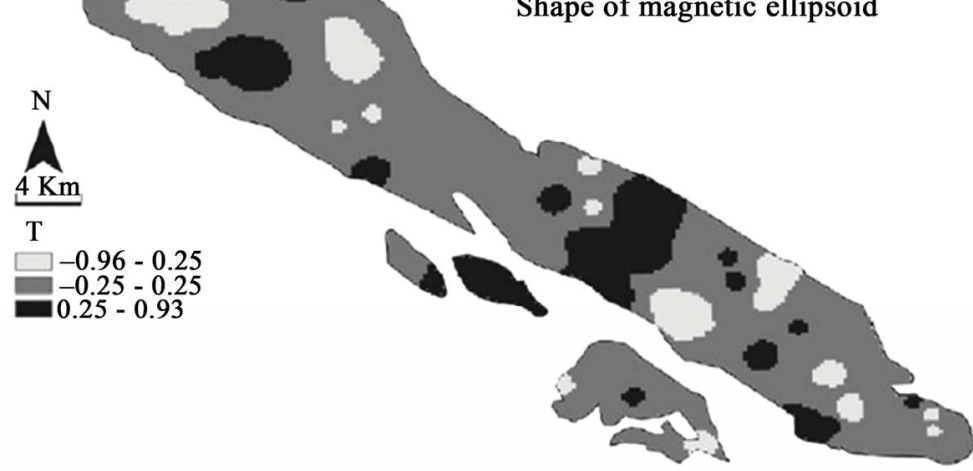

Figure 6. Contoured maps of: (a) Degree of anisotropy and (b) Shape of the magnetic fabric ellipsoid. 

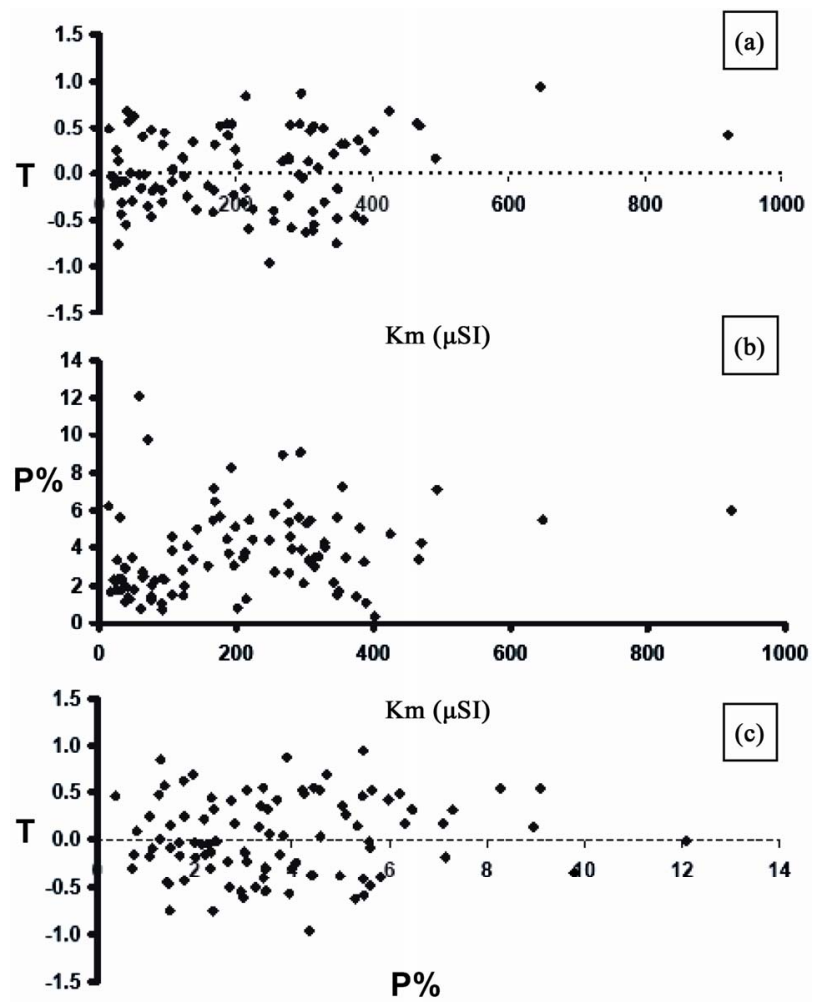

Figure 7. Correlations between: (a) Bulk susceptibility and degree of anisotropy; (b) Bulk susceptibility and the shape of the AMS ellipsoid; (c) The degree of anisotropy and the shape of the AMS.

\section{DIVIDING THE PLUTONS INTO DOMAINS BASED ON AMS SIGNATURE}

By examining the microstructures along with magnetic foliations and lineations four domains can be distinguished (Figures 8(a), (b)). The magnetic susceptibility magnitudes, Km, vary from 14 to $921 \mu$ SI (Table 1). Susceptibilities lower than $115 \mu \mathrm{SI}$ are mostly found among the monzogranite located at the southern end of the massif (Gousheh intrusion) and the altered granites to the northwest of the pluton. The intermediate susceptibility domain $(116 \leq \mathrm{K}(\mu \mathrm{SI}) \leq 260)$ occupies the throughout of the pluton mostly its NW section. Finally, susceptibilities higher than $261 \mu \mathrm{SI}$ cover most of the granodiorite of the Boroujerd pluton. The magnetic foliations and lineations mostly strike NNW-SSE and have steep dips. The lineations have NNW-SSE trends as well but they have shallow plunges:

In the northwest, close to the city of Boroujerd, domain $\mathrm{A}$ is the largest domain comprising 48 stations with a mean susceptibility of $153 \mu$ SI. With a few exceptions, the domain belongs to granodiorite. The microstructures are the sub-mylonitic to mylonitic and the anisotropy is the lowest among others (mean $\mathrm{P} \%=3.42$ ). The lineations are mostly aligned in the NW-SE direction with an average trend/plunge of $157^{\circ} / 14^{\circ}$.

Domain B is composed of 20 stations, mostly within the granodiorite with a mean susceptibility of $268 \mu \mathrm{SI}$. The lineations have NNW-SSE trends and shallow plunges, with an average trend/plunge of $178^{\circ} / 22^{\circ}$. The anisotropy degree may be rather high, between $0.8 \%$ and 9.8\% (mean P\%: 4.18), a value consistent with a strain imprint higher than in domain $\mathrm{A}$. The $\mathrm{T}$ values occupy almost the full range, from -0.61 to 0.94 .

Domain C comprises 19 stations to the south of domain B. It is made of both granodiorite (4 stations) whose susceptibility is moderate (mean $\mathrm{K}=291 \mu \mathrm{SI}$ ) and quartzdiorite ( 9 stations) with a mean $\mathrm{K}$ of $312 \mu$ SI. The outcrop along the southern border of the Boroujerd pluton, at the contact with the metamorphosed country rocks shows more deformation. The lineations have an average trend/plunge of $163^{\circ} / 35^{\circ}$. This domain has high values of the susceptibility, reaching $493 \mu \mathrm{SI}$, with a mean of 306 . The average anisotropy percentage is close to $4.1 \%$, and the shape factor is in the plano-linear field (mean $\mathrm{T}=$ 0.14 ). This deformed domain represents either the southern prolongation of the shear zone that characterizes domain $\mathrm{D}$, or represents an independent NW-SE trending fault zone parallel to SSZ.

Finally domain D, in the south is the smallest with 8 stations and has exclusively magmatic to submagmatic microstructures. The lineations have mean trend/plunge of $311^{\circ} / 27^{\circ}$. This domain is has a medium susceptibility monzogranite (mean K: $160 \mu \mathrm{SI}$ ) and covers exactly the area where the youngest bodies are observed. Site no. 75 has an exceptionally high anisotropy of $921 \mu \mathrm{SI}$. The degree of anisotropy is low to medium (mean $\mathrm{P} \%$ : 3.78) and the $\mathrm{T}$ values range from 0.44 to -0.38 with a mean of 0.1 (plano-linear).

\section{DISCUSSION}

\subsection{Microstructures}

The magnetic fabric axes are parallel to the mineral fabric axes, and these axes record the strain field (flattening plane and stretching direction) to which the magma was subjected, either during its crystallization (magmatic microstructures) or immediately after (high-temperature solid-state microstructures) [40-43]. The microscopic study and field observation of the Boroujerd pluton show that there are continuities from magmatic to mylonitic deformations and associated fabrics. This feature points clearly to a continuum of magma straining during and after its crystallization [44].

The lineations are mainly shallowly plunging and irrespective of the lithological boundaries, they mostly strike in a NW-SE direction. The similar lineation pattern in the Gousheh young body (Figure 8(a)) can be attributed to a consistent continuous tectonic regime in the region, 

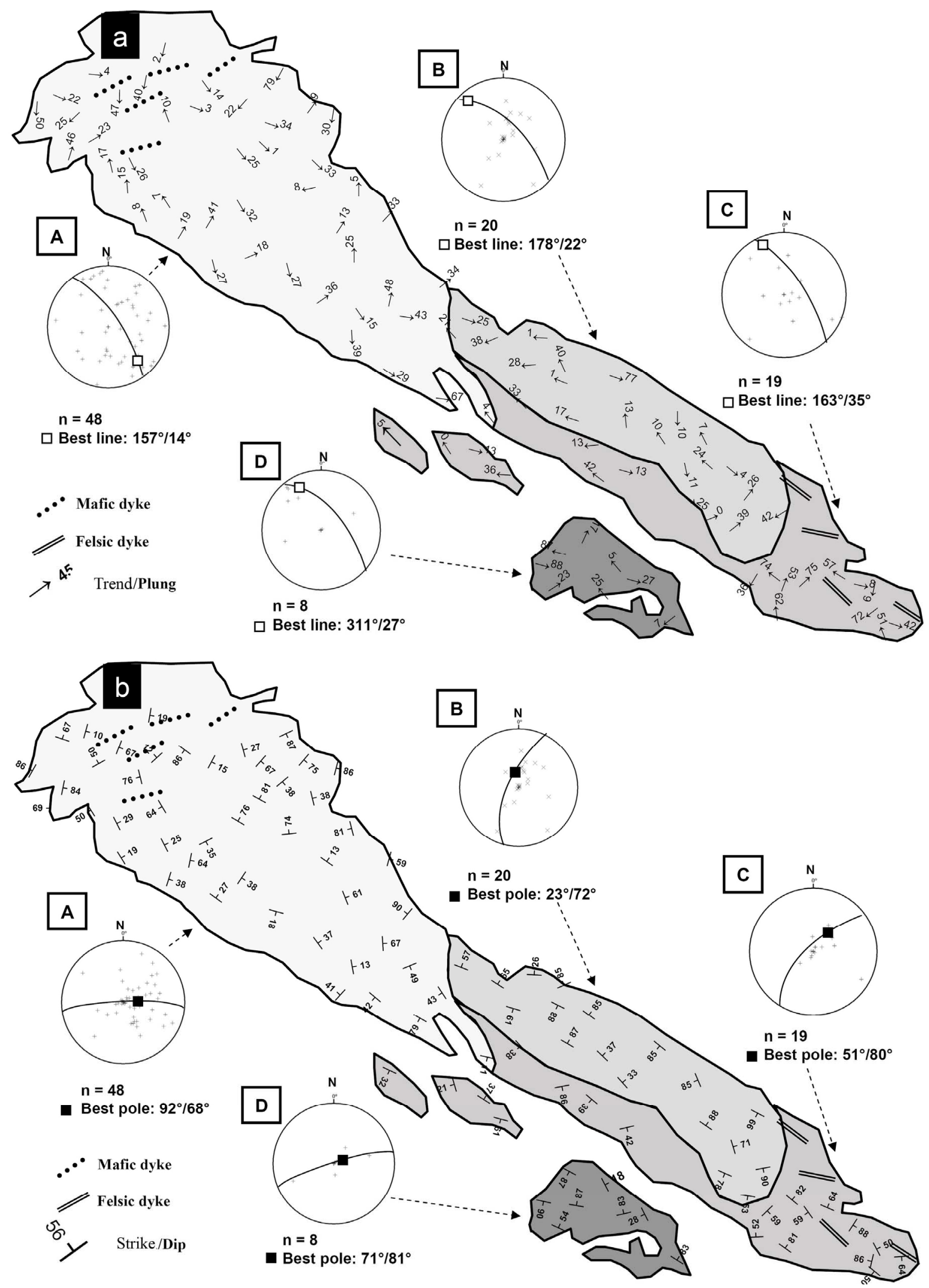

Figure 8. (a) Magnetic lineation map and contoured lower hemisphere equal area projection of magnetic lineation $\left(K_{1}\right)$ of the study area for granitoids. This plunge of $K_{1}$ is NW which display the stretching direction; (b) Magnetic foliation map and magnetic foliation poles $\left(K_{3}\right)$ of the study area. 
lasting from the middle Jurassic to the late Eocene (ca $35 \mathrm{Ma}$ ) and in consistent with continuum of deformation of the Boroujerd pluton after its emplacement and solidification. At the extremities of the Boroujerd pluton (Figure 8) structures display dextral shearing. The lineations are the best indicators of the stretching direction to which the magma was subjected while the mineral fabric was forming $[4,45,46]$. This interpretation is strongly supported by the mafic dykes that crosscut the pluton in the very northwest of Boroujerd perpendicular to the magmatic lineations (Figure 8; [47]). From a structural point of view, it is concluded that the plutons were subjected to an overall protracted N-S to NNW-SSE stretching regime during emplacement and cooling. The northeasterly-oriented oblique subduction of the Neotethys under the Central Iran led to dextral transpressive tectonism which is contemporaneous with the emplacement of the Boroujerd pluton, as inferred from regional studies [1-4].

The anisotropy is high in two parts; the southeastern part of Boroujerd pluton which experienced low temperature deformation and the northwestern part with mylonitic deformation (Figure 4). No correlation was found between $\mathrm{P} \%$ and $\mathrm{K}$, except for domain $\mathrm{D}$ where the positive correlation agrees with the magmatic deformation and low strain undergone by the monzogranite in Gousheh intrusion. The shape of AMS ellipsoid (T parameter), is relatively homogenous (27 of 95 samples show prolate and 32 of 95 oblate fabrics) and tends to increase from domain $\mathrm{D}$ (mean $\mathrm{T}=0.11$.) to domain $\mathrm{A}$ (mean $\mathrm{T}=$ 0.14 ), suggesting that an increase in flattening has accompanied the increase in deformation.

\subsection{Magnetic Parameters versus Rock-Types}

Susceptibility magnitudes naturally decrease from parts that are occupied by quartz-diorite (mean $\mathrm{K}=285 \mu \mathrm{SI}$ ), and granodiorites (mean $\mathrm{K}=183 \mu \mathrm{SI}$ ) to parts consisting of granites (mean $\mathrm{K}=159 \mu \mathrm{SI}$ ) that contain less ironbearing silicates. In the low susceptibility granite plutons, such as the Boroujerd, the magnetic susceptibility is regarded as a tool for petrographic characterization and regional mapping [47]. The study of Boroujerd shows that there is good correlation between magnetic susceptibility and the modal classification of Streckeisen (1976) through the iron-content of the rock. The map of bulk susceptibility is similar to the map of the different rock-types (Figure (5) cf. Figure 1).

\section{INTERPRETATION AND MODE OF EMPLACEMENT}

The results are of interest from a regional tectonic perspective. Syntectonic emplacement of the pluton during the main phase of deformation is demonstrated, hence new isotopic dates for the pluton (ca $172 \mathrm{Ma}$; [1]) may be used to establish the age of this Jurassic tectonic event in the SSZ. The fabrics documented using the AMS are compatible with transpressional syn-tectonic emplacement, indicating a horizontal Z-axis and an important component of horizontal stretching associated with the bulk regional deformation strain. The low angle of the magnetic lineations is interpreted as horizontal stretching in the pluton.

We conclude from this study that the Boroujerd pluton was subjected to an overall NW-SE stretching during and after its emplacement. This stretching is inferred from magnetic lineations that were mostly arranged in this direction. In some places in the pluton margins this lineation pattern is affected by shear zones. We shall therefore assume that magma stretching took place during pluton emplacement in an arc setting resulting from the oblique subduction of the western Neotethys under the Central Iran during the Jurassic. The low plunge of magnetic lineation of Boroujerd pluton argues in favour of a sillshaped body. The dextral transpressive tectonic regime [12] led to elongation of the plutons due to flattening associated with arc perpendicular shortening. This would resukt in stretching the lineations parallel to NW-SE direction in map view. The transpressional environment is likely based on geological and structural evidence throughout the SSZ.

In the transpressive model of the region, the relative motion plate results in a combination of dextral simple shearing parallel to the plate boundary and contraction nearly perpendicular to this plate boundary. The contraction caused extensive folding in the country rocks. Tikoff and Teyssier [48] argued that the $\theta=35^{\circ}$ could be the maximum value in the wrench-dominated transpression that considers $\sim 20 \%$ of slip partitioned on strike-slip faults. According to the present geographic configuration, if we assumed that the azimuth of the mean stretching direction (i.e. lineation) for the studied pluton is $\sim 190^{\circ}$ $\left(010^{\circ}\right)$, this gives $\sim 225^{\circ}\left(45^{\circ}\right)$ for the plate boundary strike and $\sim 250^{\circ}$ for the azimuth of the slip vector between Arabia and the Sanandaj-Sirjan microplate and in fine a $\sim 25^{\circ}$ for the angle between the slip vector and the plate boundary (Figure 9). However, the azimuth for domain $\mathrm{D}$ in the younger body of Gousheh is $215^{\circ}$ which may suggests an anti-clockwise rotation of Iranian plate during emplacement span of Boroujerd and Gousheh plutons (e.g. from Middle-Jurassic to Late-Eocene.

\section{CONCLUSIONS}

There was a continuum in deformation, from a magmatic state to low- $T$, and (sub)mylonitic, conditions, with similar structural patterns for both the Middle-Jurassic (Boroujerd) and Late-Eocene (Gousheh) plutons. The homogeneity and continuity of the AMS fabrics across the pluton indicate that emplacement and crystallization of 

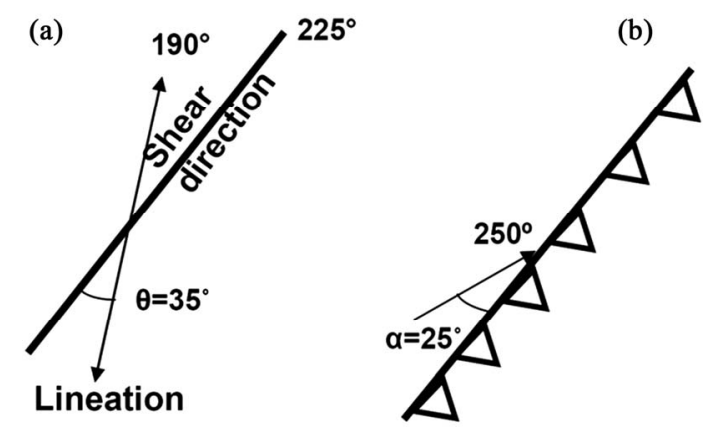

Figure 9. Possible kinematics at the eastern boundary of the Sanandaj-Sirjan microplate, for a transpression: (a) Shear parallel to plate boundary (b) Slip vector oblique to plate boundary. $\theta=35^{\circ}=$ Angle between stretching axis and the plate boundary. $\alpha=25^{\circ}=$ Angle between the slip vector and the plate boundary. $90^{\circ}=$ Azimuth of stretching axis. $190^{\circ}+35^{\circ}=225^{\circ}=$ IranArab plate boundary strike. $225^{\circ}+25^{\circ}=250^{\circ}=$ Azimuth of the slip vector between Arabia and SSZ. $\alpha$ and $\theta$ are from the analysis of Tikoff and Teyssier [48].

the Boroujerd granitoids under a similar tectonic strain field. The emplacement of the studied pluton took place in an active margin magmatic arc of SSZ during oblique subduction of the Neotethys under the Central Iran. The northern part of the Boroujerd pluton, where microstrucures indicate a (sub)mylonitic deformation might correspond to shear zones. Field and microscopic evidence show a dextral sense of movement in these zones. The elongated shape of the Boroujerd pluton (like other plutons of SSZ) and its location close to shear zones call for a close relationship between the SSZ plutonism and the shear zones. In the Boroujerd pluton, magnetic lineation plunge is too gentle to demonstrate a sill-shaped body. The low bulk susceptibility of the studied rocks is lower than $5 \times 10^{-4} \mathrm{SI}$ (except for two stations) which indicates that paramagnetic minerals were dominant components (biotite and hornblende). The stretching trend may suggest that the boundary strike of the Iranian plate was oriented $225^{\circ}$.

\section{ACKNOWLEDGEMENTS}

The Toulouse magnetic laboratory of UMR CNRS 5563 where all AMS measurements were performed is gratefully acknowledged. The authors thank M. Najafi for his help with collection of AMS samples.

\section{REFERENCES}

[1] Ahmadi-Khalaji, A., Esmaeily, D., Valizadeh, M.V. and Rahiumpour-Bonab, H. (2007) Petrology and geochemistry of the granitoid complex of Boroujerd, Sanandaj-Sirjan Zone, Western Iran. Journal of Asian Earth Sciences, 29, 859-877. doi:10.1016/j.jseaes.2006.06.005

[2] Ghalamghash, J., Nédéléc, A., Bellon, H., Vosoughi Abedini, M. and Bouchez, J.L. (2009) The Urumieh plu- tonic complex (NW Iran): A record of the geodynamic evolution of the Sanandaj-Sirjan zone during Cretaceous times-Part I: Petrogenesis and K/Ar dating. Journal of Asian Earth Sciences, 35, 401-415. doi:10.1016/j.jseaes.2009.02.002

[3] Asnaashary, A., Hassanzadeh, J., Wernicke, B., Schmitt, A.K., Axen, G. and Horton, B. (2009) Middle Jurassic flare-up and Cretaceous magmatic lull in the central Sanandaj-Sirjan arc, Iran. An analogy with the southwestern United States. Proceedings of the Geological Survey of Amrica Annual Meeting, 4.

[4] Shahbazi, H., Siebel, W., Pourmoafee, M., Ghorbani, M., Sepahi, A.A., Shang, C.K. and Vousoughi Abedini, M. (2010) Geochemistry and U-Pb zircon geochronology of the Alvand plutonic complex in Sanandaj-Sirjan Zone (Iran): New evidence for Jurassic magmatism. Journal of Asian Earth Sciences, 39, 668-683. doi:10.1016/j.jseaes.2010.04.014

[5] Petford, N., Lister, J.R. and Kerr, R.C. (1994) The ascent of felsic magmas in dykes. Lithos, 32, 161-168. doi:10.1016/0024-4937(94)90028-0

[6] Borradaile, G.J. and Henry, B. (1997) Tectonic applications of magnetic susceptibility and its anisotropy. Earth Science Reviews, 42, 9-93. doi:10.1016/S0012-8252(96)00044-X

[7] Bouchez, J.L. (1997) Granite is never isotropic: An introduction to AMS studies in granitic rocks. In: Bouchez, J.L., Hutton, D.H.W. and Stephens, W.E., Eds., Granite: From Segregation of Melt to Emplacement Fabrics, Kluwer Academic, Dordrecht, 95-112.

[8] Bouchez, J.L. (2000) Anisotropie de susceptibilité magnétique et fabrique des granites. Comptes Rendus de l'Academie de Science de Paris, 330, 1-14.

[9] Borradaile, G.J. (1988) Magnetic susceptibility, petrofabrics and strain. Tectonophysics, 156, 1-20. doi:10.1016/0040-1951(88)90279-X

[10] Rochette, P., Jackson, M. and Aubourg, C. (1992) Rock magnetism and the interpretation of anisotropy of magnetic susceptibility. Reviews of Geophysics, 30, 209-222. doi:10.1029/92RG00733

[11] Berberian, F. and Berberian, M. (1981) Tectono-plutonic episodes in Iran. In: Gupta, H.K. and Delany, F.M., Eds., Zagros Hindukosh, Himalaya Geodynamic Evolution, American Geophysical Union, Washington DC, 5-32. doi:10.1029/GD003p0005

[12] Ghalamghash, J., Bouchez, J.L., Vosoughi Abedini, M. and Nédéléc, A. (2009) The Urumieh plutonic complex (NW Iran): A record of the geodynamic evolution of the Sanandaj-Sirjan zone during Cretaceous times-Part II: Magnetic fabrics and plate tectonic reconstruction. Journal of Asian Earth Sciences, 36, 303-317.

[13] Stöcklin, J. (1968) Structural history and tectonics of Iran; a review. American Association of Petroleum Geologists Bulletin, 52, 1229-1258.

[14] Darvishzadeh, A. (1991) Geology of Iran. Neda Publication, Tehran, 1991.

[15] Alavi, M. (1994) Tectonic of the Zagros orogenic belt of Iran new data and interpretations. Tectonophysics, 229, 
211-238. doi:10.1016/0040-1951(94)90030-2

[16] Davoudzadeh, M. (1997) Iran. In: Moores, E.M. and Fairbridge, R.W., Eds., Encyclopedia of European and Asian Regional Geology, Encyclopedia of Earth Sciences Series, Chapman and Hall, London.

[17] Dehghani, G. and Makris, J. (1983) The gravity field and crustal structure of Iran. Geological Survey of Iran, 51, 51-68.

[18] Masoudi, F. (1997) Contact metamorphism and pegmatite development in the region SW of Arak, Iran. PhD Thesis, The University of Leeds, UK.

[19] Masoudi, F., Yardley, B.W.D. and Cliff, R.A. (2002) $\mathrm{Rb}-\mathrm{Sr}$ geochronology of the pegmatites, plutonic rocks and hornfels in the region south-west of Arak, Iran. Journal of Science (Iran), 13, 249-254.

[20] Razavi, S.M.H., Masoudi, F. and Sarikhani, H. (2008) Petrology of gosheh-nelkhast intrusions in the region NE of Borujerd, Iran. Journal of Science, Islamic Azad University, 18, 10-20.

[21] Nezafati, N. (2006) Au-Sn-W-Cu-Mineralization in the Astaneh-Sarband Area, West Central Iran, including a comparison of the ores with ancient bronze artifacts from Western Asia. PhD Thesis, Eberhard-Karls-Universität Tübingen, Germany.

[22] Bouchez, J.L., Guillet, P. and Chevalier, F. (1981) Structures d'écoulement liés à la mise en place du granite de Guérande (Loire Atlantique, France). Bulletin De La Societe Geologique De France, 7/Xxiii, 387-399.

[23] Paterson, S.R., Vernon, R.H. and Tobish, O.T. (1989) A review of criteria for the identification of magmatic and tectonic foliations in granitoids. Journal of Structural Geology, 11, 349-363. doi:10.1016/0191-8141(89)90074-6

[24] Leblanc, D., Gleizes, G., Roux, L. and Bouchez, J.L. (1996) Variscan dextral transpression in the French Pyrenees: New data from the Pic des Trois-Seigneurs granodiorite and its country rocks. Tectonophysics, 261, 331345. doi:10.1016/0040-1951(95)00174-3

[25] Bouchez, J.L., Delas, C., Gleizes, G. and Nédéléc, A. (1992) Submagmatic microfractures in granites. Geology, 20, 35-38. doi:10.1130/0091-7613(1992)020<0035:SMIG >2.3.CO;2

[26] Arzi, A.A. (1978) Critical phenomena in the rheology of partially melted rocks. Tectonophysics, 44, 173-184. doi:10.1016/0040-1951(78)90069-0

[27] Fernandez, A. and Gasquet, D.R. (1994) Relative rheological evolution of chemically contrasted coeval magmas: Example of the Tichka plutonic complex. Contribution to Mineralogy and Petrology, 116, 316-326. doi:10.1007/BF00306500

[28] Rochette, P. (1987) Magnetic susceptibility of the rock matrix related to magnetic fabric studies. Journal of Structural Geology, 9, 1015-1020. doi:10.1016/0191-8141(87)90009-5

[29] Jover, O., Rochette, P., Lorand, J.P., Maeder, M. and Bouchez, J.L. (1989) Magnetic mineralogy of some granites from the French Massif Central; origin of their lowfield susceptibility. Physics of the Earth And Planetary
Interiors, 55, 79-92. doi:10.1016/0031-9201(89)90235-5

[30] Launeau, P. (1990) Analyse numerique des images et orientations preferentielles de forme des agregats polyphasés; Application á l'analyse cinematique des granites. $\mathrm{PhD}$ Thesis, Univ. Paul Sabatier, Toulouse, France, 180 Pages.

[31] Gleizes, G., Leblanc, D., Olivier, Ph. and Bouchez, J.L. (2001) Strain partitioning in a pluton during emplacement in transpressional regime: The example of the Néouvielle granite (Pyrenees). International Journal of Earth Sciences (Geologische Rundschau), 90, 325-340.

[32] Gleizes, G., Crevon, G., Asrat, A. and Barbey, P. (2006) Structure, age and mode of emplacement of the Hercynian Borde res-Louron pluton (Central Pyrenees, France). International Journal of Earth Sciences (Geologische Rundschau), 95, 1039-1052. doi:10.1007/s00531-006-0088-4

[33] Bouchez, J.L., Gleizes, G., Djouadi, T. and Rochette, P. (1990) Microstructure and magnetic susceptibility applied to emplacement kinematics of granites: The example of the Foix pluton (French Pyrenees). Tectonophysics, 184, 157-171. doi:10.1016/0040-1951(90)90051-9

[34] Hrouda, F., Taborska, S., Schulmann, K., Jezeck, J. and Dolejs, D. (1999) Magnetic fabric and rheology of co-mingled magmas in Nasavrky Plutonic Complex (E Bohemia): Implications for intrusive strain regime and emplacement mechanisms. Tectonophysics, 307, 93-111. doi:10.1016/S0040-1951(99)00121-3

[35] McNulty, B.A., Tobisch, O.T., Cruden, A.R. and Gilder, S. (2000) Multistage emplacement of the Mount Givens pluton Central Sierra Nevada batholith. GSA Bulletin, 112, 119-135.

doi:10.1130/0016-7606(2000)112<119:MEOTMG $>2.0 . C$ $\underline{\mathrm{O} ; 2}$

[36] Ahadnejad, V. (2010) Petrology, geochemistry and emplacement mechanism of Malayer plutonic complex, west Iran, using Anisotropy of magnetic Susceptibility (AMS). PhD thesis, University of Tehran, 294 Pages.

[37] Hrouda, F. (1982) Magnetic anisotropy of rocks and its application in geology and geophysics. Geophysical Surveys, 5, 37-82. doi:10.1007/BF01450244

[38] Benn, K. (1994) Overprinting of magnetic fabrics in granites by small strains: Numerical modelling. Tectonophysics, 233, 153-162. doi:10.1016/0040-1951(94)90238-0

[39] Olivier, Ph., de Saint-Blanquat, M., Gleizes, G. and Leblanc, D. (1997) Homogeneity of granite fabrics at the metre and dekametre scales. In: Bouchez, J.L., Hutton, D.H.W. and Stephens, W.E., Eds., Granite: From Segregation of Melt to Emplacement Fabrics, Kluwer Academic, Dordrecht, 113-127.

[40] Aranguren, A., Larrea, F.J., Carracedo, M., Cuveas, J. and Tubia, J.M. (1997) The Los Pedroches batholith (southern Spain). Polyphase interplay between shear zones in transtension and setting of granites. In: Bouchez, J.L., Hutton, D.H.W. and Stephens, W.E., Eds., Granites: From Segregation of Melt to Emplacement Fabrics, Kluwer Academic, Dordrecht, 215-229.

[41] De Saint-Blanquat, M. and Tikoff, B. (1997) Develop- 
ment of magmatic to solid-state fabrics during syntectonic emplacement of the Mono Creek granite, Sierra Nevada batholith. In: Bouchez, J.L., Hutton, D.H.W. and Stephens, W.E., Eds., Granites: From Segregation of Melt to Emplacement Fabrics, Kluwer Academic Publishers, Dordrecht, 231-252.

[42] Guillet, P., Bouchez, J.L. and Wagner, J.J. (1983) Anisotropy of magnetic susceptibility and magmatic structures in the Guérande granite massif (France). Tectonics, 2, 419-429. doi:10.1029/TC002i005p00419

[43] Benn, K., Paterson, S.R., Lund, S., Pignotta, G.S. and Kruse, S. (2001) Magmatic fabrics in batholiths as markers of regional strains and plate kinematics: Example of the Cretaceous Mt. Stuart batholith. Physics and Chemistry of the Earth $(A), \mathbf{2 6}, 343-354$. doi:10.1016/S1464-1895(01)00064-3

[44] Bouillin, J.P., Bouchez, J.L., Lespinasse, P. and Pêcher, A. (1993) Granite emplacement in an extensional setting: An AMS study of the magmatic structures of Monte Capanne (Elba, Italy). Earth and Planetary Science Letters, 118, 263-279. doi:10.1016/0012-821X(93)90172-6
[45] Ahadnejad, V., Valizadeh, M.V. and Esmaeily, D. (2008) The role of shear zone on the emplacement of Malayer Granitoid Complex, NW Iran. Journal of Applied Sciences, 8, 4238-4250. doi:10.3923/jas.2008.4238.4250

[46] Mazhari, S.A., Bea, F., Amini, S., Ghalamghash, J., Molina, J.F., Montero, P., Scarrow, J.H. and Williams, I.S. (2009) The Eocene bimodal Piranshahr massif of the Sanandaj Sirjan Zone, NW Iran: A marker of the end of the collision in the Zagros orogen. Journal of the Geological Society, 166, 53-69. doi:10.1144/0016-76492008-022

[47] Gleizes, G., Nédélec, A., Bouchez, J.L., Autran, A. and Rochette, P. (1993) Magnetic susceptibility of the MontLouis Andorra ilmenite-type granite (Pyrenees): A newtool for the petrographic characterization and regional mapping of zoned granite pluton. Journal of Geophysical Research, 98, 4317-4331. doi:10.1029/92JB01590

[48] Tikoff, B. and Teyssier, C. (1994) Strain modeling of displacement-field partitioning in transpressional orogens. Journal of Structural Geology, 16, 1575-1588. doi:10.1016/0191-8141(94)90034-5 